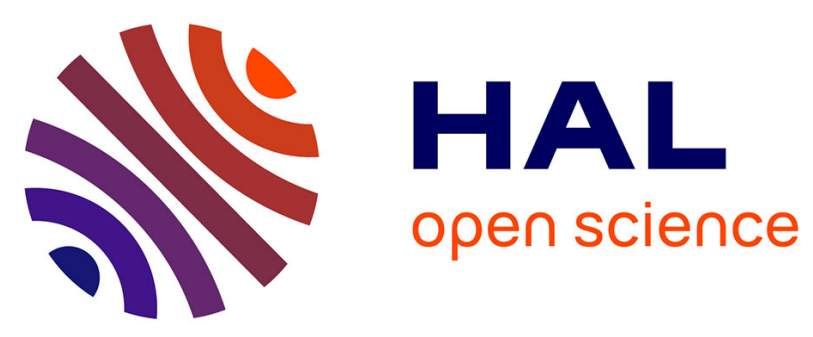

\title{
Prediction of net hepatic release of glucose using a "hybrid" mechanistic model in ruminants applied to positive energy balance
}

Lahlou Bahloul, Isabelle Ortigues Marty, Jean Vernet, Helène Lapierre, Pierre Noziere, Daniel Sauvant

\section{To cite this version:}

Lahlou Bahloul, Isabelle Ortigues Marty, Jean Vernet, Helène Lapierre, Pierre Noziere, et al.. Prediction of net hepatic release of glucose using a "hybrid" mechanistic model in ruminants applied to positive energy balance. 4. International Symposium on Energy and Protein Metabolism and Nutrition (ISEP), Sep 2013, Sacremento, United States. 3 p. hal-01356561

\section{HAL Id: hal-01356561 \\ https://hal.science/hal-01356561}

Submitted on 3 Jun 2020

HAL is a multi-disciplinary open access archive for the deposit and dissemination of scientific research documents, whether they are published or not. The documents may come from teaching and research institutions in France or abroad, or from public or private research centers.
L'archive ouverte pluridisciplinaire HAL, est destinée au dépôt et à la diffusion de documents scientifiques de niveau recherche, publiés ou non, émanant des établissements d'enseignement et de recherche français ou étrangers, des laboratoires publics ou privés. 


\title{
Prediction of net hepatic release of glucose using a 'hybrid' mechanistic model in ruminants applied to positive energy balance
}

\author{
L. Bahloul I, I. Ortigues-Marty ${ }^{I}, J$. Vernet ${ }^{l}$, H. Lapierre ${ }^{3}$, P. Nozièrel and D. Sauvant $^{2}$

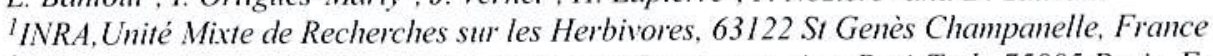 \\ ${ }^{2}$ UMR, Modélisation Systémique Appliquée aux Ruminants, AgroParisTech, 75005 Paris, France: \\ sauvant@agroparistech.fr. \\ ${ }^{3}$ Agriculture and Agri-Food Canada, Sherbrooke, QC JIMOC8, Canada
}

\section{Introduction}

Ruminants depend on hepatic gluconeogenesis to meet most of their metabolic demand for glucose which relies on availability of precursors from diet supply and animal requirements (Loncke et al., 2010). Several mechanistic models of the metabolic fate of nutrients across the liver exist that have been parameterized for dairy cows. They cannot be directly used to predict hepatic gluconeogenesis in all types of ruminants in different physiological status. A hybrid mechanistic model of nutrient fluxes across the liver is presently being developed (Bahloul et al., 2012), that is calibrated empirically based on meta-analysis (Sauvant and Mertens, 2008) to be applicable to all types of ruminants in different physiological status and to usual nutritional practices. The objectives of the present work were to test the hybrid liver model in its present state of development to simulate the net hepatic release of glucose when the glucogenic/ketogenic/nitrogenous nutrient profile entering the liver varies. This first application of the model was limited to ruminants in positive calculated energy balance, in which the nutrient fate across the liver is mostly directed by mass action laws.

\section{Material and methods}

Net veno-arterial fluxes of nutrients correspond to the inputs (net portal appearance, NPA) and outputs (net splanchnic release, NSR) of the mechanistic model. Nutrients considered are: acetate $(\mathrm{C} 2)$, propionate $(\mathrm{C} 3)$, butyrate $(\mathrm{C} 4)$, glucose, lactate, $\beta$-hydroxybutyrate $(\mathrm{BHB})$, total amino acids (TAA), urea, $\mathrm{NH}_{3}, \mathrm{O}_{2}, \mathrm{CO}_{2}$ and the absorbed fatty acids. Their flows are expressed in mmol of $\mathrm{C} / \mathrm{h} / \mathrm{BW}$ except for $\mathrm{NH}_{3}$ expressed in mmol of $\mathrm{N} / \mathrm{h} / \mathrm{BW}$. Ten hepatic compartments are included: $\mathrm{C} 2, \mathrm{C} 3, \mathrm{C} 4, \mathrm{BHB}$, glycogen, protein, glucose, lactate, TAA and $\mathrm{CO}_{2}$. Conversion fluxes between compartments, including metabolic compartments summarizing the Krebs cycle, represent the main hepatic metabolic pathways. The model based on mass action laws is adjusted on empirical relationships of the net hepatic transfer of nutrients derived by meta-analysis (Loncke, 2009) from FLORA database, allowing estimation of NSR of nutrients. The empirical equation used to predict glucose NSR was based on the sum of the NPA of precursors (Loncke et al., 2010), modified to take into account all AA potentially convertible to glucose. Indeed, if only the NPA of glucogenic AA is considered, a deficit of carbon is calculated to meet glucose output. Sets of experimental data, representative of nutritional practices representing different combinations of ketogenic, glucogenic and nitrogen nutrient inputs, were used to adjust parameters of the conversion fluxes, in cattle and sheep, only in calculated positive energy balance. Nutritional status ranged from 1 to $5 \times \mathrm{ME}$ and 1.4 to $6.7 \times$ metabolizable protein maintenance requirements. Parameters were adjusted so that the simulated model outputs converge at best with the values predicted by empirical relationships. The model was evaluated by: (1) calculating the full $\mathrm{C}$ balance across the liver; and (2) by comparing outputs (NSR) of glucose simulated by the model with values predicted by the empirical relationships.

\section{Results and discussion}

The full $\mathrm{C}$ balance across the liver simulated by the model (Figure 1) indicates a tight agreement between $\mathrm{C}$ outputs and inputs, with a small deficit averaging $0.0021 \mathrm{~mol} \mathrm{C} / \mathrm{d}$. Comparison between the model simulated and the empirically predicted NSR of glucose (Figure 2) shows a good (93\%) 


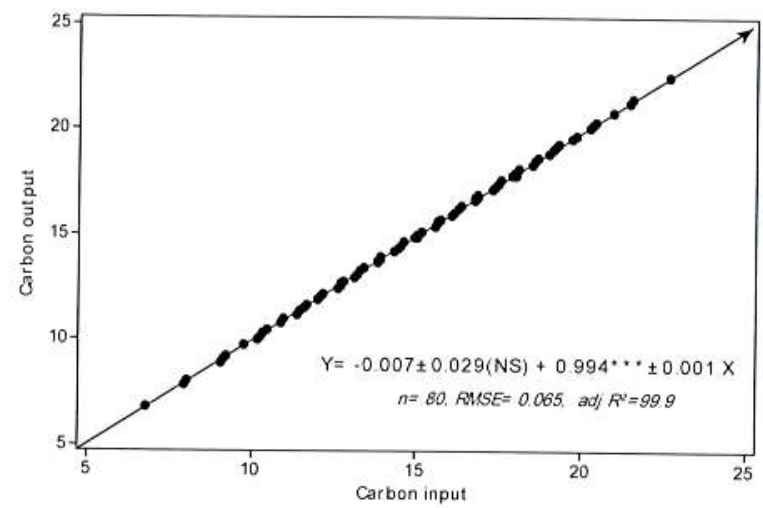

Re

Bah

Lon

Lon

Sau

Figure 1. Relationship between the carbon output (Y) simulated by the model and the carbon input (X) in mmol of $C / h / B W, * * * \mathrm{P}<0.001$.

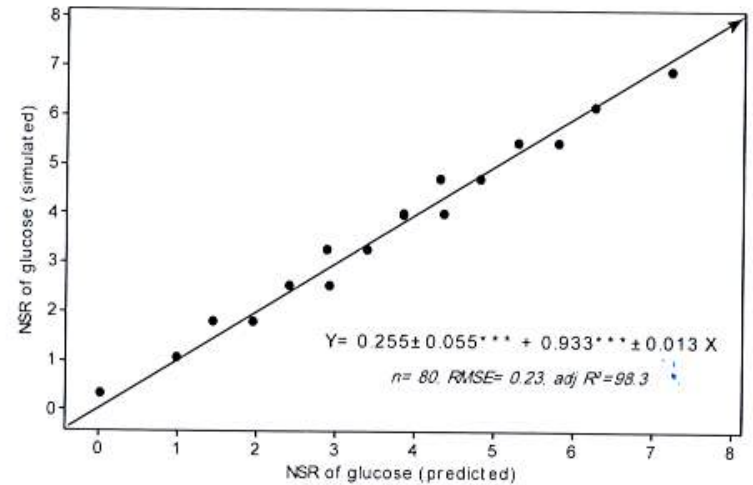

Figure 2. Relationship between the NSR of glucose $(Y)$ simulated by the model and predicted by structural relationship $(X)$ in mmol of $C / h / B W, * * * \mathrm{P}<0.001$.

simulation. For C 3 and TAA, the major glucogenic nutrients, the simulated outputs compare well with the values predicted by the structural relationship. Parameters of mass action laws obtained by model adjustment show that $93 \% / \mathrm{h}$ and $173 \% / \mathrm{h}$ of intrahepatic pool of TAA and $\mathrm{C} 3$ is metabolized to oxaloacetate $(\mathrm{OA})$ respectively; $124 \%$ of intrahepatic pool of OA is converted to glucose. Almost, all TAA up taken by the liver (73\%) appeared used for neoglucogenesis. The hepatic uptake of C3 $(91 \%)$ seems to be converted completely to glucose, only $19 \% / \mathrm{h}$ and $0.8 \% / \mathrm{h}$ of intrahepatic pool of $\mathrm{C} 3$ are released and converted to pyruvate respectively. A strength of the approach is to identify situations responsible for poor adjustments: an underestimation $(0.34 \mathrm{mmol}$ of $\mathrm{C} / \mathrm{h} / \mathrm{BW})$ of the simulated NSR glucose is observed at elevated TAA NPA $(>3 \mathrm{mmol}$ of $\mathrm{C} / \mathrm{h} / \mathrm{BW})$.

The hybrid model based strictly on mass action laws simulates well the prediction of hepatic release of glucose for ruminants in positive energy balance. The model was found to be stable in term of $\mathrm{C}$ balance, with a small negligible deficit in $\mathrm{C}$. The next step consists on the application of the model to ruminants in negative energy balance. If necessary, regulations representing hepatic metabolism will be introduced to take account interaction between nutrients and tissues (nutrient requirements).

\section{Acknowledgements}

Financial support from INZO and Limagrain is acknowledged. 


\section{References}

Bahloul, L., D. Sauvant, J. Vernet, H. Lapierre, P. Nozière and I. Ortigues-Marty, 2012. Mechanistic modeling based on meta-analysis : prediction of the net hepatic fluxes of energetic nutrients in ruminant. Can. J. Anim. Sci. 92, 559-560.

Loncke, C., 2009. Modélisation des relations entre l'alimentation et les flux splanchniques de nutriments énergetiques chez le ruminant. Thèse de doctorat, AgroParisTech. France.

Loncke, C., P. Noziere, S. Lemosquet, J. Vernet, H. Lapierre, D. Sauvant and I. Ortigues-Marty, 2010. Splanchnic release of glucose in relation to dietary supply and animal performances. Renc. Rech. Ruminants 17, 317.

Sauvant, D. and D. Mertens, 2008. Use of meta-analysis to build a mechanistic model of responses of rumen digestion to dietary fibre in cattle. Can. J. Anim. Sci. 88, 730. 


\section{Energy and protein metabolism and nutrition in sustainable animal production}

$4^{\text {th }}$ International Symposium on Energy and Protein Metabolism and Nutrition

Sacramento, California, USA

9-12 September 2013

EAAP publication No. 134

edited by:

James W. Oltjen

Ermias Kebreab

Hélène Lapierre

Wageningen Academic
a b I i s h e r s 
Buy a print copy of this book at www.WageningenAcademic.com/eaap I 34

ISBN: 978-90-8686-227-6 e-ISBN: $978-90-8686-781-3$ DOI: $10.3920 / 978-90-8686-78 \mid-3$

ISSN 007 I-2477

\section{Photo cover: Jim Oltjen and Romeo Capell}

First published, 2013

(C) Wageningen Academic Publishers The Netherlands, 2013
This work is subject to copyright. All rights are reserved, whether the whole or part of the material is concerned. Nothing from this publication may be translated, reproduced, stored in a computerised system or published in any form or in any manner, including electronic, mechanical, reprographic or photographic, without prior written permission from the publisher:

Wageningen Academic Publishers P.O. Box 220

6700 AE Wageningen

The Netherlands

www.WageningenAcademic.com copyright@WageningenAcademic.com

The individual contributions in this publication and any liabilities arising from them remain the responsibility of the authors.

The designations employed and the presentation of material in this publication do not imply the expression of any opinion whatsoever on the part of the European Association for Animal Production concerning the legal status of any country. territory, city or area or of its authorities, or concerning the delimitation of its frontiers or boundaries.

The publisher is not responsible for possible damages, which could be a result of content derived from this publication. 